\title{
PERCEPTION OF THE TEACHER FUNCTION AND A-MOTIVATION OF THE INSTITUTES IN THE CONSTITUENCY OF THE PRIMARY COURSE AIR-France OF BOUAKE (COTE D'IVOIRE)
}

\author{
MARTIN ARMAND SADIA*, DRISSA SORO2, KOUAKOU MLAN HOUFLET ${ }^{3}$
}

\author{
${ }^{1}$ UFR CMS, Universite Alassane Ouattara. ${ }^{2}$ Ecole Primaire Air-France 2, IEPP Bouake-Air France. ${ }^{3}$ Ecole des educateurs \\ permanent, Institut National de la Jeunesse et des Sports-Abdjan \\ *Email: sadiamartino@yahoo.fr
}

Received: 25 October 2020, Revised and Accepted: 9 December 2020

\begin{abstract}
The aim of this study, which is taking place in the territorial jurisdiction of the Inspectorate of Preschool and Primary Education (IEPP) of Bouake d'Air-France, is to assess the link between perceptions of teacher function among teachers and their motivation. The premise behind the study is that perceptions influence teacher motivation. The theoretical anchor of this study is the theory of reasoned action of Ajzen (1991). To test this hypothesis, a sample of 86 teachers was randomly selected and represents $20 \%$ of the total number of teachers estimated at 432. The information-gathering techniques are: the documentary research, the questionnaire, consisting of 11 items to be informed and the inventory of motivations at work (EMT-31). The data collected was processed using Excel software. The main findings reveal that teachers have negatively dominant perceptions of their profession and are almost motivated. In addition, a link between "negative perception" and "a-motivation" has been established, although this link is not too strong in relation to the phi contingency coefficient $(0.22)$.
\end{abstract}

Keywords: Perception, Teacher function, Teacher motivation, A-motivation.

(c) 2021 The Authors. Published by Innovare Academic Sciences Pvt Ltd. This is an open access article under the CC BY license (https://creativecommons.org/licenses/by/4.0/). DOI: https://dx.doi.org/10.22159/ijoe.2021v9i1.40623 . Journal homepage: https://innovareacademics.in/journals/index.php/ijoe

\section{INTRODUCTION}

For the past ten years, teachers have been an essential part of the education system and have faced many difficulties that have led to untimely strikes. The persistence of these difficulties seems to have altered the professional pride of teachers. In Côte d'Ivoire, it is not uncommon to hear this sentence: "The children of today are dummies; they don't know anything." Several studies looking at the factors that explain the underperformance of Ivorian students include the lack of follow-up and support from parents of pupils (Lahire, 1999), pedagogical reforms, the inadequacy of teaching processes to the African context, the poor quality of teaching in relation to the diversification of teacher recruitment, etc. However, studies that have identified the issue of teacher motivation as factors of academic failure do not exist in our knowledge.

This topic is of social interest insofar as the behaviour of amotivated teachers can have consequences for social cohesion; to the extent that the attitude of some teachers towards their profession is likely to cause many students out of school in the Ivorian education system with its corollaries namely juvenile delinquency, social misfits and children in conflict with the law who pose a threat to Ivorian society. In addition, a-motivated behaviours can serve as a model that children could later reproduce in their adult working lives. This could have disastrous effects on the country's development. Finally, amotivation can lead to psychological ailments in the teacher that can lead to a drop-out.

\section{BACKGROUND OF THE STUDY}

Article 3 of Decree 93-607 of 2 July 1993, under common terms of application of the general status of the Public Service, states that "public servants are recruited by means of competition unless derogations are provided by decrees." Article 6 of the same text specifies, as an exception, that "for teacher training institutions, the ministers responsible for teaching organise the competitions in collaboration with the Minister in charge of the Public Service." On the basis of this provision, intensive recruitment operations have been undertaken; increasing from one (01) Ivorian teachers in 1912 to 144597 teachers (preschool, primary, general secondary and technical) in 2015 (DPSE, 2016). This important recruitment is part of the dynamics of the Education For All (EFA) policy and above all due to the massification of the school population. The teachers thus recruited are trained in educational animation and training centres (CAFOP). In addition, the State has carried out a wage increase in the education training sector. Despite this, there is a high rate of absenteeism among teachers, especially in the Primary Education Inspectorate of Bouake Air-France, as revealed in the following table:

Table 1: Authorized teacher absences (2017-2018)

\begin{tabular}{|c|c|c|c|c|c|c|c|}
\hline Month & January & February & March & April & May & September & October \\
\hline $\begin{array}{c}\% \text { of } \\
\text { absences }\end{array}$ & $6.56 \%$ & $8.08 \%$ & $13.63 \%$ & $2.02 \%$ & $5.80 \%$ & $1.50 \%$ & $9.29 \%$ \\
\hline
\end{tabular}

Source: IEPP Air-France's absence authorization register.

When they are present in class, they are observed to use the hours of classes to either browse social networks or to maintain chats among colleagues. The few who teach do not prepare the courses. Indeed, the exploratory survey revealed that almost all tenured teachers do not present their notebooks for the director's visa. In addition, they do not provide educational materials, i.e. instructional sheets, summary tables (student nominative list, pupil ages, pupils' schooling, etc.) daily newspaper books, call logs and the monthly distribution of educational programmes (Iepp Air-France, 2018). Their speeches are peppered with self-stigmatization and selfdeprecation. These findings raise the question: is there a link between teachers' perception of their function and the motivation observed in their behaviour? Our hypothesis states that perception is a variable that influences the motivation of Ivorian teachers. In the scientific literature, authors reveal that motivation depends on socio-economic conditions (Hansez et al., 2005; Ndagijimana, 2013). According to Delvaux, Desmarez, Dupriez, Lothaire \& Veinstein (2013), the variable that makes it possible to understand the motivation of teachers is the low success rate of students. As for Jouck (2015); Rabia (2010); Toh (2011) it is rather, the lack of administrative support for teachers and working conditions. Finally, other authors 
mention the overload of tasks to be accomplished (Geraldine, 2016) and the loss of attractiveness of the teaching profession due to the evolution of teaching work (Maroy, 2008). From the above, it appears that none of these authors approached the issue from the point of view of the correlation between their own perception of the teacher's profession and their amotivation.

\section{OBJECTIVE OF THE STUDY}

The objective of this study was to assess the link between teacher perceptions of teaching function and their motivation.

\section{HYPOTHESIS}

The premise behind the study is that perceptions influence teacher motivation.

\section{METHODOLOGY}

\section{Ethics rules}

Access to the land for the collection of information was made possible thanks to the favourable follow-up given by the Inspector of Primary Education, Head of the Bouake Air-France constituency to our research request mail. Second, we sought the agreement of the participants through a free consent form in which the purpose of the study and its anonymous nature were clearly formulated. For example, the subjects participating in this study issued informed consent.

\section{Site and participants}

This study takes place in the jurisdiction of the Inspectorate of Preschool and Primary Education (IEPP) of Air-France. It is limited to the west by the IEPP Belle-ville, to the south by the IEPP N'gattakro and Jebonoua and Didievi. All 73 Public Primary Schools (PPEs), including 50 urban and 23 rural schools included in this inspection, were taken into account by the study.

The total number of teachers that constitutes the survey base is 432 individuals. At this level, we randomly applied $20 \%$. Thus, thanks to the simple random sampling technique, the sample size is 86 subjects.

\section{Method and techniques for collecting data}

The techniques used to collect information are: the documentary research, the questionnaire, consisting of 11 items to be informed and the inventory of motivations at work (Blais, Lachance, Briere, Riddle, \& Vallerand, 1993).

Documentary research helped to shed light on the knowledge on the subject in order to identify the originality of this study. In addition, it has provided access to the various pedagogical supervision sheets of school principals and counsellors in order to apprehend the various A-motivation events among teachers. In total, 125 sheets were consulted and crossreferenced in order to gain access to the different motivationa behaviours of the teachers. The 13 items were stored in a grid. The second tool is the questionnaire consisting of 16 preformed questions that provide information on teachers' perceptions of teaching function. Finally, the Blais et al. (1993) test was used to measure the motivation of officers in the various schools targeted. The answers to this test are on a seven-point Likert scale ranging from "doesn't match at all" (1) to "corresponds very strongly" (7). The psychometric qualities of this scale have been disassembled in the past by Blais et al. (1993) which indicate that the Cronbach alpha coefficient varies from 0.57 to 0.78

The theoretical anchor of this study is the theory of reasoned action of Ajzen (1991). The strong idea of this theory is that the choices of individuals' behaviours are thought-out, reasoned and thoughtful choices. All individual human behavior is in this perspective placed under the control of the will and it is therefore the result of a behavioral intention.

The data collected was processed using Excel software.

\section{RESULTS}

The two variables studied in this research, "perception of teaching function" and "A-motivation" were taken from a descriptive perspective, prior to the evaluation of correlation privilege. As such, the questionnaire reveals that the majority of institutes surveyed have a negative perception of the function of teacher.

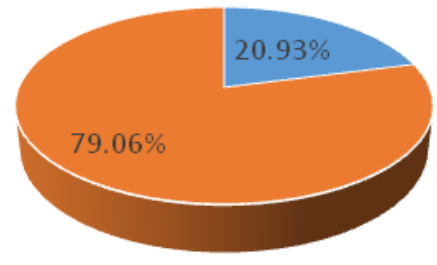

- Positive perception of the profession of teachers

- Negative perception of teachers

Source: results of our 2019 survey

Fig. 1: Teachers' distribution by type of perception

It appears from this figure 1 that three-fourths of teachers have a negative perception of their profession. The perceptions expressed by the two strata above, result as follows:

Table 2: Teacher perceptions of the teaching profession

\begin{tabular}{|c|c|c|c|}
\hline S. No. & Items & Number expressed & Percentage \\
\hline 01 & Very restrictive and demanding & 15 & 17.44 \\
\hline 02 & Teachers stripped of his power & 10 & 11.63 \\
\hline 03 & Teacher occupation too stressful & 13 & 15.12 \\
\hline 04 & Low-paid work overload & 21 & 24.41 \\
\hline 05 & Feelings of helplessness, frustration and anger & 9 & 10.47 \\
\hline 06 & It's a woman's job & 00 & 00 \\
\hline \multicolumn{2}{|c|}{ SUB-TOTAL 1 } & 68 & 79.07 \\
\hline 07 & exciting work & 4 & 2.65 \\
\hline 08 & Valued work in the community & 2 & 3.33 \\
\hline 09 & Benefit of school holidays & 3 & 5.81 \\
\hline 10 & Allows a regular update of knowledge & 5 & 4.65 \\
\hline 11 & A civil servant like any other & 4 & 20.93 \\
\hline \multicolumn{2}{|c|}{ SUB-TOTAL 2 } & 18 & 100 \\
\hline
\end{tabular}

Source: results of our 2019 survey 
Depending on their frequency of occurrence in the survey, negative perceptions of the "very restrictive and demanding" nature of the teacher's profession, the "low-paid work overload" and the "very stressful" nature are dominant in the thinking of primary education actors. What is their level of motivation?

The figure 2 answers this question.

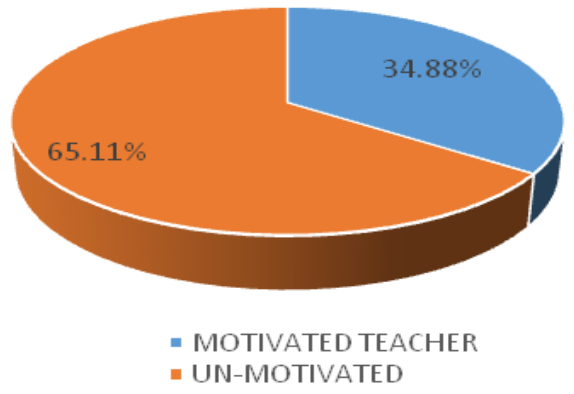

Source: results of our 2019 survey

Fig. 2: Teachers' distribution according to motivational degree
It is noted in the figure 2 that the total number of motivated teachers is roughly equal to half of those who are A-motivated. In other words, there are more A-motivated teachers in this riding than their motivated peers.

This A-motivation has been observed in class situations. The synthesis of 125 observation grids of the pedagogical supervisors, namely: the principals of schools, the counsellors and the pedagogical inspectors administered over the period 2005 to 2019, allows to observe the following manifestations of the a-motivation of teachers in class (Table 3).

Table 3 shows that the A-motivation observed among teachers concerns pedagogical activities, professional awareness and social and human skills.

Do the perceptions thus described influence the A-motivation observed in teachers?

The table 4 provides information on the link between these two characteristics.

The first analysis that emerges from this table that in each of the modalities of perception studied (negative perception or positive perception), we meet both motivated teachers and those A-motivated. The second analysis suggests that the perception of teachers' profession influences teacher motivation. In addition, the phi contingency coefficient $(0.22)$ indicates that this link, which is not too close to 1 , is moderately strong. It can therefore be inferred that there may be other factors to explore in future studies. What is the meaning of these results?

Table 3: Demonstration of a-motivation in class

\begin{tabular}{|c|c|c|}
\hline Behaviour & Effective & Percentage \\
\hline The teacher does not teach with love and selflessness & 45 & 52.33 \\
\hline The teacher does not prepare the lessons (lack of course preparations) & 56 & 65.12 \\
\hline The teacher does not correct homework & 50 & 58.14 \\
\hline The teacher does not keep the records up to date & 54 & 62.79 \\
\hline The teacher is not punctual & 55 & 63.95 \\
\hline The teacher is not diligent (absenteeism) & 60 & 69.76 \\
\hline The teacher has no initiative & 59 & 68.60 \\
\hline The teacher has no knowledge and professional skills & 38 & 44.19 \\
\hline The teacher has no work power and performance & 53 & 61.63 \\
\hline The teacher does not have a sense of public service & 51 & 59.30 \\
\hline Inadequacy between the teacher's professional skills and the knowledge to be taught & 57 & 66.28 \\
\hline The teacher has neither a social sense nor a sense of human relations & 36 & 41.86 \\
\hline The teacher's loyalty is not above reproach & 36 & 41.86 \\
\hline
\end{tabular}

Sources: Results of our 2019 survey

Table 4: Link between perceptions and a-motivation

\begin{tabular}{|c|c|c|c|}
\hline Perceptions & Motivation & A-motivation & Total \\
\hline Positive perception of the profession of teachers & 10 & 08 & 18 \\
\hline Negative perception of teachers & 20 & 48 & 68 \\
\hline Total & 30 & 56 & 86 \\
\hline
\end{tabular}

Sources: Results of our 2019 survey

$\operatorname{chi}^{2}=4.28, \mathrm{df}=1, \mathrm{p}=0.038$ (There is a significant difference, $\mathrm{p}<0.05$ )

\section{Discussion}

Perception of the job of a negative-dominant teacher The results of the study revealed at the first level that teachers' perceptions of their profession are overwhelmingly negative. The analysis of the items identifies two main groups of factors. Some are purely pedagogical and others related to the feeling of dissatisfaction felt after carrying out a teacher's work that they consider difficult and trying. The negative pedagogical perceptions that teachers have of themselves can be explained by a kind of unconscious integration of social cliches that are not very valuable about their corporation. This is evident from Lesli's (2001) study, which states that "teachers are influenced by the images of passivity, neglect and technical incompetence attributed to them by the public authorities and the university." However, these results contrast with those of "teachers are proud of their profession, they would like more recognition of the hierarchy and better opportunities for evolution. But 49\% would like to change their position in the context of national education and $21 \%$ would like to leave the educational framework" (SE-Unsa, 2014).

Pre-eminence of A-motivation among teachers

The second result of the study is related to the pre-eminence of a-motivated behaviour among the teachers interviewed. This amotivation reflects the loss of the sense of mission of a public service officer (Beaucourt \& Louart, 2002), whose primates are "the disinterest in collective results and non-adherence to the settlement project" and above all degradation of social relations and personally. In addition, the manifestations of a- 
motivation among teachers coincide with Bleau's (2005) definition, which refers to a state of lack of intent to act. This situation of a-motivation has various causes. For Ouedraogo, (2011), it is the psychological factors linked to contradictions and vagaries professional situations that make it possible to understand this motivation. From his point of view, Tournemenne \& Leclercq (2016) explains the a-motivation by (inadequate) conditions in which education is provided. Relationship between perception and a-motivation The results mainly reveal that there is a link between teachers' perceptions of their profession and their A-motivation. This result confirms our hypothesis. It is explained more by the theory of reference, namely the theory of reasoned action of Ajzen. Indeed, perceptions as judgment, the result of reasoning are a cognitive construct, an antecedent that predicts and explains the A-motivation behaviors observed in teachers. In other words, as the teachings represent the profession of teachers, as they invest in their work. This result validates the work of Hackman \& Oldham (1976); Delobbe (2007); Karsenti, Collin, \& Dumouchel (2013) and Rojo and Minier (2015). This work has in common to recognize that a-motivation is triggered by the perception of work. Similarly, Hansez et al. (2005) assert that there is a link between abandonment of professional activities and reasons (perception) related to psychosocial risks such as inadequate equipment, high workload or high time constraints of work, etc.

\section{CONCLUSION}

This study, which aims to assess the link between perception of teaching function and A-motivation among Ivorian teachers, helps to determine the dominant perceptions and the manifestation of a-motivation. On the other hand, the study was able to establish a link between the two characteristics studied, even if this link is not too strong in relation to the phi contingency coefficient. This reality suggests, first and for the short term, that awareness-raising activities and actions to enhance the teaching function be put in place. Finally, it is important to consider another study whose objective will be to identify all other factors of teacher motivation. It is a matter of scrutinizing all "economic, organisational, technological and cultural constraints, and their interactions with the needs, values and aspirations" of teachers.

\section{ACKNOWLEDGEMENT}

We extend our sincere thanks to Mrs. Guei nee Padre Marceline, Inspector of Preschool and Primary Education and to all her staff for facilitating the completion of this study. We will not forget the efforts of the principals and the frank collaboration of the teachers without whom this research project would not have known this outcome.

\section{AUTHORS CONTRIBUTIONS}

All the authors have contributed equally.

\section{CONFLICT OF INTEREST}

Declared none.

\section{REFERENCES}

- Ajzen, I. (1991). The theory of planned behavior. Organizational Behavior and Human Decision Processes, 50, 179-211.

- Beaucourt, C., \& Louart., P. (2002). Gerer la motivation dans les entreprises publiques: Par les valeurs, les assurances ou les incitations. In L'Harmattan (Ed.), La motivation dans le secteur public (pp. 169-190). Paris, France: L'Harmattan.

- Blais, M. R., Lachance, L., Vallerand, R. J., Briere, N. M., \& Riddle, A. (1993). Echelle de motivation au travail (EMT-31). Revue Quebecoise de Psychologie, 14(3), 185-215.
- $\quad$ Bleau, C. (2005). Motivation, absenteisme, reussite et decrochage scolaire : Analyse de leurrelation (Masters thesis, Université de Montréal, Canada). Retrieved from https://papyrus.bib.umontreal.ca/xmlui/handle/1866/17678

- Delobbe, N. (2007). Factors of motivation and transfer training in learning: A sequential study in the context of a learning to the leadership. Psychologie du Travail et des Organisations, 13(3), 71-88.

- Delvaux, B., Desmarez P., Dupriez, V., Lothaire S., \& Veinstein, M. (2013). Les enseignants debutants en Belgique francophone: Trajectoires, conditions d'emploi et position sur le marche du travail. Les Cahiers de recherche du Girsef, 92.

- FSI-ESM. (sd). La motivation du personnel https://d1n7iqsz6ob2ad.cloudfront.net/document/pdf, consulte le 20 octobre 2020.

- $\quad$ Geraldine, V. (2016). Les facteurs de motivation des enseignants sont-ils predicteurs du phenomene du Turnover? Dimensions croisees entre les enseignants prescolaires et primaires et les enseignants debutants et experimentes (Masters thesis, Universite Catholique de Louvain, Belgium). Retrieved from https://dial.uclouvain.be/memoire/ucl/en/object/thesis:6975

- Hackman, J. R., \& Oldham, R. G. (1976). Motivation through the design of work: Test of a theory. Organizational Behavior and Human Performance, 16(2), 250-279. doi.org/10.1016/00305073(76)90016-7

- Hansez, I., Bertrand, F., Keyser, V. D., \& Peree, F. (2005). Fin de carriere des enseignants: vers une explication du stress et des retraites

prematurees. Le travail humain, 68(3), 193-223. doi.org/10.3917/th.683.0193

- Jouck A-M. (2015). Quel est le degre de satisfaction des enseignants primaires en communaute germanophone? (Masters thesis, Universite de Liege, Belgium). Retrieved from https://docplayer.fr/84973515-Quel-est-le-degre-desatisfaction-des-enseignants-primaires-en-communautegermanophone.html

- $\quad$ Karsenti, T., Collin, S., \& Dumouchel, G. (2013). Le decrochage enseignant: Etat des connaissances. International Review of Education, 59(5), 549-568. doi.org/10.1007/s11159-0139367-z

- Lesli, I. (2001). La construction sociale de la profession enseignante : Un reseau d'histoires, Revue education et francophonie. $\quad$ Retrieved from https://www.acelf.ca/c/revue/revuehtml/29-1/05-Lelis.html

- Maroy, C. (2008). Perte d'attractivite du metier et malaise enseignant. Recherche \& formation, 57, 23-38. doi.org/10.4000/rechercheformation.810

- $\quad$ Ndagijimana, J-B. (2013). Les facteurs de la faible motivation et leurs effets sur l'apprentissage. Cas des eleves de l'Ecole Normale Primaire (ENP/TTC) au Rwanda (Doctoral thesis, Universite de Bouake, Ivory Coast). Retrieved from https://tel.archivesouvertes.fr/tel-00920269

- Ouedraogo, R. M. (2011). Strategies pour l'amelioration des conditions de travail des enseignants et leur retention dans les ecoles en Afrique. Addis-Abeba, Ethiopia : UNESCO-IICBA.

- Rabia, E. A. (2010). Les enseignants marocains: Entre engagement et prise de distance, Memoire, Universite de Rouen. Retrieved https://www.memoireonline.com/02/12/5218/Lesenseignants-marocains-entre-engagement-et-prise-dedistance.html

- $\quad$ Rojo, S., \& Minier, P. (2015). Les facteurs de stress reconnus comme sources de l'abandon de la profession enseignante au secondaire au Quebec Education et francophonie, 43(2), 219-240. doi.org/10.7202/1034493ar

- Syndicat des enseignants du premier degre et du second degre. (2014). Comment valoriser la part invisible du metier d'enseignant? https://vocationservicepublic.fr/commentvaloriser-la-part-invisible-du-metier-d-enseignant.

- Toh, A. (2017). Precarisation de la profession enseignante au primaire 
Sadia et al.

Innovare Journal of Education, Vol 9, Issue 1, 2021, 17-21

Côte d'Ivoire. Formation et profession, 25(2), 20-34 doi.org/10318162/fp.2017.335.

- $\quad$ Tournemenne, F., \& Leclercq, J. (2016). Comment les conditions de travail dans lesquelles l'enseignant remplacant construit son identite professionnelle influencent sa motivation a persister dans le metier? (Masters thesis, Universite catholique de Louvain, Belgium)

Retreived

from 